\title{
BMJ Global Health Introduction: migration and health in social context
}

\section{Emily Mendenhall (D) ,1,2 Seth M Holmes Health in Social Context Working Group}

To cite: Mendenhall E, Holmes SM, On behalf of the Migration and Health in Social Context Working Group. Introduction: migration and health in social context. BMJ Global Health 2021;6:e005261. doi:10.1136/ bmjgh-2021-005261

EM and SMH contributed equally.

This article is submitted as part of the BMJ Global Health "Migration and Health in Social Context" collection edited by Emily Mendenhall and Seth M. Holmes.

Received 3 February 2021 Accepted 8 February 202

Check for updates

C Author(s) (or their employer(s)) 2021. Re-use permitted under CC BY-NC. No commercial re-use. See rights and permissions. Published by BMJ.

For numbered affiliations see end of article.

Correspondence to Dr Seth M Holmes;

sethmholmes@berkeley.edu
While many argue that health is a universal human right, ${ }^{1}$ global health equity has proven difficult to achieve. ${ }^{2}$ The social determination of health systematically structures which people are made more or less vulnerable to sickness and disease. ${ }^{3}$ Simultaneously, health professionals and health systems have discretion in terms of how and whether they treat people, and this discretion may compound or ameliorate health inequities. Such discretion exists in the midst of unequal power relations between patients and health professionals that can be immense in certain contexts.

The collection of Analysis articles, "Migration and Health in Social Context", lays bare the ways in which social, political and economic structural factors impede or facilitate health among the most vulnerable migrants seeking care from clinical settings globally. The three articles consider clinical cases from around the world to define the social science concepts of structural vulnerability, deservingness and flourishing as they illuminate the care of transnational migrants who are unauthorised or undocumented in states that systematically marginalise such care-seekers due to increasingly anti-immigrant, xenophobic, racist or nationalist sentiments. We recognise that, for some immigrants, movement itself can enhance health outcomes; however, for others, who are the focus of this collective work, migration is one in a series of processes producing structural vulnerability in health.

Migration is a 'core determinant of health and wellbeing,' and many people receive differential treatment based on their migration status. ${ }^{45}$ Salway et al argue in a recent issue of the $B M J$ that, "We urgently need to improve our understanding of, and responses to, the health needs of mobile and ethnically diverse populations'. ${ }^{6}$ In response, these articles highlight the importance of social context to global health. Each article considers real clinical cases from around the world in order to show how medical social science concepts are important and relevant to global health clinicians, policy-makers, and health system planners.

These papers consider cases of care-seekers reliant on public healthcare systems, seeking clinical medicine from the state for various conditions. The article focusing on structural vulnerability demonstrates how systemic social inequities undermine how clinicians are able to care for care-seekers who are unauthorised or undocumented. The cases emphasise the precarity in which people seek as well as provide care, particularly within contexts of transnational mobility. The article elucidating deservingness reveals how some patients are perceived to be and treated as more deserving of care because of their ethnicity, ability to pay, or nationality-regardless of their legal eligibility for a particular kind of care. The ethnographic case studies reveal that the structures that frame one's deservingness are not only situated nationally but also framed by global factors that impact who gets sick and why. Finally, the article developing the social science concept of flourishing emphasises how clinical settings can move beyond the biological confines of disease to facilitate healing for unauthorised migrants. Drawing on three cases studies, the authors show how the capacity to flourish is influenced by cultural expectations, social relationships, and the structural determinants that shape and constrain migrants' lives.

This collection is designed to bring social science concepts to bear on clinical contexts in order to unlock the importance of social forces to global health and equity. Combining social science with clinical cases, this collection serves as a tool box for clinicians, including those in training, as well as health system leaders and policy-makers who are concerned with caring for whole persons in contexts of migration. These papers seek to clarify the social determination of disease, ${ }^{7}$ highlight how such processes affect undocumented or 
unauthorised migrants, and centre whole persons in the pursuit of equity in global health and health care.

\section{Author affiliations}

${ }^{1}$ Edmund A Walsh School of Foreign Service, Georgetown University, Washington, District of Columbia, USA

${ }^{2}$ Developmental Pathways for Health Research Unit, Faculty of Health Sciences, University of the Witwatersrand, Johannesburg, South Africa

${ }^{3}$ Humanities and Social Sciences, University of California San Francisco School of Medicine, San Francisco, California, USA

${ }^{4}$ Paoli Calmettes Chair, IMeRA Mediterranean Institute for Advanced Study, Marseille, France

${ }^{5}$ Society and Environment, Medical Anthropology and Public Health, University of California Berkeley, Berkeley, CA, USA

Acknowledgements We would like to thank Akasemi Newsome from the Institute of European Studies at UC Berkeley, Miriam Magaña Lopez from the UC Berkeley Institute for the Study of Societal Issues, and Nate Kral from Georgetown University for their brilliant work bringing together scholars from many parts of the world to discuss and learn from each other.

Collaborators The Migration and Health in Social Context Working Group: John Fredrik Askjer (University of Oslo), Lauren Carruth (American University), Ernesto Castañeda (American University), Heide Castañeda (University of South Florida), Shahanoor Akter Chowdhury (NextSkills Consulting, Dhaka, Bangladesh), Yusupha Dibba (Partners in Health Sierra Leone), Katharine M. Donato (Georgetown University), Raphael Frankfurter (University of California Berkeley and San Francisco), Jérémy Geeraert (Humboldt University Berlin and Centre Marc Bloch), Anne Kveim Lie (University of Oslo), Miriam Magaña Lopez (University of California Berkeley), Carlos Martinez (University of California Berkeley and San Francisco), Carlos Piñones-Rivera (Universidad Arturo Prat), Ursula Probst (Freie Universität Berlin), James Quesada (San Francisco State University), Nasima Selim (Freie Universität Berlin), Lahra Smith (Georgetown University), Sarah S. Willen (University of Connecticut), Nina Zeldes (Freie Universität Berlin), Hansjörg Dilger (Freie Universität Berlin).

Contributors Both authors conceived of, drafted and revised the article.

Funding We would like to acknowledge support from the DAAD German Academic Exchange Service, the Peder Sather Center for Advanced Study, the UC Berkeley Institute of European Studies, the Berkeley Center for Social Medicine, the UC
Berkeley Institute for the Study of Societal Issues, the IMeRA Mediterranean Institute for Advanced Study, the Institute Paoli Calmettes, and the Georgetown University Global Futures Initiative.

Competing interests None declared.

Patient consent for publication Not required.

Provenance and peer review Not commissioned; internally peer reviewed.

Data availability statement There are no data in this work.

Open access This is an open access article distributed in accordance with the Creative Commons Attribution Non Commercial (CC BY-NC 4.0) license, which permits others to distribute, remix, adapt, build upon this work non-commercially, and license their derivative works on different terms, provided the original work is properly cited, appropriate credit is given, any changes made indicated, and the use is non-commercial. See: http://creativecommons.org/licenses/by-nc/4.0/.

\section{ORCID iDs}

Emily Mendenhall https://orcid.org/0000-0002-5826-1321

Seth M Holmes http://orcid.org/0000-0002-2244-2868

\section{REFERENCES}

1 World bank. World Health organization and international bank for reconstruction and development / the world bank. tracking universal health coverage: 2017 global monitoring report, 2017. Available: http://pubdocs.worldbank.org/en/193371513169798347/2017-globalmonitoring-report.pdf [Accessed 14 May 2020].

2 Marmot M. Health equity in England: the Marmot review 10 years on. BMJ 2020;368:m693.

3 Bourgois P, Holmes SM, Sue K, et al. Structural vulnerability: Operationalizing the concept to address health disparities in clinical care. Acad Med 2017;92:299-307.

4 Castañeda $\mathrm{H}$, Holmes SM, Madrigal DS, et al. Immigration as a social determinant of health. Annu Rev Public Health 2015;36:375-92.

5 Abubakar I, Aldridge RW, Devakumar D, et al. The UCL-Lancet Commission on migration and health: the health of a world on the move. The Lancet 2018;392:2606-54.

6 Salway S, Holman D, Lee C, et al. Transforming the health system for the UK's multiethnic population. BMJ 2020;368:m268.

7 Spiegel JM, Breilh J, Yassi A. Why language matters: insights and challenges in applying a social determination of health approach in a north-south Collaborative research program. Global Health 2015;11:9. 